\title{
Evidence and Proportionality in Free Movement Cases - The Impact of Scotch Whisky
}

Oliver Bartlett and Angus MacCulloch*

\begin{abstract}
Market interventions to protect public health are likely to be subject to EU law challenge as contrary to the free movement rules. In Scotch Whisky the CJEU stressed the importance of defined public health objectives and supporting evidence in the analysis of whether interventions are justified as 'appropriate' and 'necessary'. This article considers the wider implications of this judgment for the application of the proportionality test in free movement cases and in the case of innovative interventions that are adopted on a complex evidence base. The article argues that the unusual development that Scotch Whisky made to the CJEU's wider trend towards greater engagement with evidence should be treated with caution, and that it is possible for national courts to apply the new guidance on the role of evidence in the proportionality analysis with sensitivity. The article also argues that policymakers must now be more aware of how they frame innovative interventions and the evidence supporting them.
\end{abstract}

\section{Keywords}

Keywords: EU Law, Free Movement, Public Health, Proportionality, Alcohol Pricing, Evidence, Framing.

\section{Introduction}

In 2012 the Scottish Parliament passed the Alcohol (Minimum Pricing) (Scotland) Act 2012, which provided for minimum unit pricing (MUP) for alcoholic beverages. That legislation was immediately subject to legal challenge by a number of alcohol producer interest groups. The lead claimant, the Scotch Whisky Association, was backed by a number of pan-European alcohol trade bodies; such as spiritsEUROPE (representing European spirit producers) and Comité européen des entreprises vins (representing European wine producers). ${ }^{1}$ The litigation delayed the introduction of MUP in Scotland for six years, ${ }^{2}$ and will have repercussions for any government that has introduced or is considering introducing MUP $^{3}$ or any similarly novel public health intervention that will impact trade between EU

\footnotetext{
Department of Law, Maynooth University, and Law School, Lancaster University. The authors would like to thank the participants at the $43^{\text {rd }}$ KBS Symposium, Mark Butler, John Holmes, Paula O'Brien, Barry Rodger, James Sweeney, and the anonymous reviewers for their helpful comments on earlier drafts. We take sole responsibility for any errors or omissions.

1 Scotch Whisky Association, Petitioners [2013] CSOH 70.

2 MUP came into effect on 1 May 2018. See: Scottish Government, Minimum Unit Pricing of Alcohol Consultation Report: Analysis of Responses (Scottish Government 2018).

3 In Ireland The Public Health (Alcohol) Act 2018 was enacted on 17 October 2018, having been introduced as a Bill in December 2015, and contains provisions for an MUP calculated according to the number of grams of alcohol in a beverage: see https://www.oireachtas.ie/en/bills/bill/2015/120/ (last accessed 13 August 2019). In Wales the Public Health (Minimum Price for Alcohol)(Wales) Act 2018 on 9 August 2018, and the
} 
Member States. It will also have far wider implications for proportionality analysis outside either public health or free movement spheres. It is already clear that the new thinking is having a profound impact in relation to, for instance, proportionality analysis within judicial review. ${ }^{4}$

In this paper we firstly set out the way in which the Court of Justice of the European Union (CJEU) developed the framework used to assess the legality of interventions in the market in Scotch Whisky. We then argue that Scotch Whisky constitutes an unusual step forward in the CJEU's ongoing movement towards greater engagement with evidence and proof in internal market cases, and examine how this new development is being handled by the national courts called upon to apply it. We finish by assessing the impact that Scotch Whisky will have upon the way in which Member State governments approach the use of evidence in innovative and experimental, yet trade-restrictive, measures, and the implications of the litigation for the role of domestic courts in proportionality analysis.

\section{The Judgment of the Court of Justice in Scotch Whisky}

\section{Hindrance to Trade}

Article 34 of the Treaty on the Functioning of the European Union (TFEU) prohibits Member States from placing '[q]uantitative restrictions on imports and all measures having equivalent effect'. Quantitative restrictions on imports are import quotas or bans, while measures having equivalent effect to a quantitative restriction (MEQRs) are defined in Dassonville as, 'all trading rules enacted by Member States which are capable of hindering, directly or indirectly, actually or potentially, intracommunity trade'. ${ }^{5}$ That definition has proven to be very broad indeed. ${ }^{6}$ In the Trailers ${ }^{7}$ case, the CJEU consolidated the ways in which a measure might be caught by the Article 34 TFEU prohibition, and adopted a new 'market access' test which was developed further in Mickelsson and Roos. ${ }^{8}$

This market access test has been used in most subsequent Article 34 TFEU cases, including Scotch Whisky. When the CJEU applied the Trailers test to the MUP scheme introduced under the 2012 Act, ${ }^{9}$ it found that:

'the fact that the legislation ... prevents the lower cost price of imported products being reflected in the selling price to the consumer means, by itself, that that legislation is capable of hindering the access to the United Kingdom market of alcoholic drinks that are lawfully marketed in Member States ... and constitutes therefore a measure having an effect equivalent to a quantitative restriction within the meaning of Article $34 \mathrm{TFEU}^{\prime}{ }^{10}$

commencement of the legislation has been delayed until 2020 due to Portugal issuing a detailed opinion on the legislation following its notification to the European Commission.

4 See, for instance, Rostron v Guilford BC [2017] EWHC 3141 (Admin).

5 Case 8/74 Procureur du Roi v Dassonville EU:C:1974:82 [1974] ECR 837, 5.

6 See, for example, Peter Oliver, 'Of trailers and jet skis: is the case law on article 34 TFEU hurtling in a new direction?' (2010) 33(5) Fordham International Law Journal 1423, and Ioannis Lianos, 'In Memoriam Keck: The Reformation of the EU Law on the Free Movement of Goods' (2015) 40(2) European Law Review 225.

7 Case C-110/05 Commission v Italian Republic EU:C:2009:66.

8 Case C-142/05 Mickelsson and Roos EU:C:2009:336 - see, in particular, 26.

9 Case C-333/14 Scotch Whisky Association v Lord Advocate EU:C:2015:845. See Oliver Bartlett, 'Minimum Unit Pricing for Alcohol May Not be a Proportionate Public Health Intervention' [2016] European Journal of Risk Regulation 218, and Alberto Alemanno, 'Balancing free movement and public health: The case of minimum pricing of alcohol in Scotch Whisky' (2016) 53 Common Market Law Review 1037.

10 Scotch Whisky, ibid, 32. 
This strong protection of price competition, as a mechanism that drives trade flows and therefore market integration, is a long-standing feature of the EU law. ${ }^{11}$ Here it simply finds a new expression in the Article 34 TFEU case law. Any attempt to directly manipulate the 'free formation of prices'12 by Member States will therefore be subject to significant legal scrutiny.

\section{Objective Justification}

The protection of public health is one of the grounds upon which national measures that breach Article 34 TFEU can be justified, but only if the measure is, 'appropriate for securing the achievement of the objective pursued and does not go beyond what is necessary in order to attain it'. ${ }^{13}$ The proportionality principle dictates that when choosing to restrict trade to achieve a legitimate objective a Member State should choose the least restrictive measure that effectively achieves the legitimate objective. This question was at the centre of the Scottish MUP litigation.

On behalf of the Scottish Government, the Lord Advocate argued that the 2012 Act, as set out in its Business and Regulatory Impact Assessment, ${ }^{14}$ pursued a 'twofold objective', of 'reducing, in a targeted way, both the consumption of alcohol by consumers whose consumption is hazardous or harmful, and also, generally, the population's consumption of alcohol'. ${ }^{15}$ Moderate drinkers in the general population were targets, 'albeit only secondarily'. ${ }^{16}$ The Petitioners, the SWA and other trade bodies, as well as the European Commission ${ }^{17}$ and several Member States, argued that the introduction of MUP was not 'necessary' to protect public health as it was possible to do so through increases in alcohol excise duties. Excise increases, they argued, could protect public health as effectively, if raised to increase prices to the same level as MUP, but would not have as restrictive an effect on trade; as all products would be affected by an increase in excise and low-cost products would maintain their cost, and price, advantages in comparison with higher cost products.

The CJEU dealt with the issue of appropriateness very succinctly. The CJEU reiterated that a measure would be appropriate if it 'genuinely reflects a concern to secure the attainment of that objective in a consistent and systematic manner'. ${ }^{18}$ As the Scottish Government could show that MUP was one of a suite of measures it had adopted as part of a wider alcohol strategy this part of the test was easily satisfied.

The issue of necessity proved to be more complex. The CJEU recognised that increasing taxation could effectively discourage consumption of alcohol 'without impinging on the free formation of prices'. ${ }^{19}$ It also accepted the argument that a taxation measure was 'liable to be less restrictive of trade' than MUP, which it characterised as a 'serious obstacle to [market] access... and to the operation of fair

11 See for instance: Case C-82/77 Openbaar Ministerie (Public Prosecutor) v Jacobus Philippus van Tiggele EU:C:1978:10; C-197/08 Commission v France EU:C:2010:111.

12 Scotch Whisky (CJEU), n 9, 44.

13 Scotch Whisky (CJEU), n 9, 33.

14 Scottish Government, Final Business and Regulatory Impact Assessment for Minimum Price Per Unit Of Alcohol As Contained In Alcohol (Minimum Pricing) (Scotland) Bill (2012)

15 Scotch Whisky (CJEU), n 9, 34.

16 Ibid.

17 Detailed opinion from the Commission on Notification 2012/0394/UK on the draft Alcohol (minimum price per unit) (Scotland) Order, reproduced by BBC Scotland at BBC News, 'Minimum alcohol pricing: Position of the European Commission' (2013) <http://www.bbc.co.uk/news/uk-scotland-scotland-politics-22368551> (last accessed 13 August 2019).

18 Scotch Whisky (CJEU), n 9, 37.

19 Ibid, 44. 
competition' ${ }^{20}$ Yet MUP would still be considered necessary if increased taxation could not achieve the objectives pursued by the Scottish government as effectively. On this comparative effectiveness test, the approaches of the Scottish courts and the CJEU differ sharply. ${ }^{21}$

In the Outer House, at first instance, Lord Doherty concluded that the objective pursued by the Scottish Government was, 'the reduction of alcohol consumption, but in particular the reduction of such consumption by hazardous and harmful drinkers', ${ }^{22}$ and that MUP is 'intended to strike at alcohol misuse and overconsumption'. ${ }^{23}$ MUP was not introduced to 'reduce consumption, including consumption by hazardous and harmful drinkers, to the maximum extent possible regardless of possible economic or social consequences. ${ }^{\prime 24}$ The Lord Ordinary concluded that since MUP was clearly targeted at harmful and hazardous consumption, this made it the most effective way of achieving the Scottish Government's objectives:

'there is inherent in the Act ... a judgment as to the level of protection of health and life the measures are designed to achieve. There is also a judgment that the best way of maximising reductions in sales, consumption and harm is to focus price increases on cheaper alcohol. ${ }^{25}$

The CJEU, however, focussed on the 'twofold' nature of the objective as initially set out by the Scottish Government, and applied the same logic it had used in prior tobacco manufacturer pricing case law, in which increased taxation was seen as a more proportionate mechanism for protecting public health than the imposition of minimum prices: ${ }^{26}$

'The objective of ensuring that the prices of those drinks are set at high levels can adequately be pursued by their increased taxation, since increases in excise duties must sooner or later be reflected in increased retail selling prices ... the fact that the case-law cited in the preceding paragraph concerns tobacco products does not mean that it is inapplicable to the main proceedings, which concern the trade in alcoholic drinks. In the context of national measures which have as their objective the protection of human life and health, and irrespective of the particular characteristics of each product, an increase in the prices of alcoholic drinks can be achieved, as was the case with respect to tobacco products, by increased taxation ... the fact that increased taxation of alcoholic drinks entails a generalised increase in the prices of those drinks ... does not appear, in the light of the twofold objective ... to lead to the conclusion that such increased taxation is less effective than the measure chosen ... the fact that an increased taxation measure may be capable of procuring additional benefits as compared with the imposition of an $\mathrm{MPU}$, by contributing to the achievement of the general objective of combating alcohol misuse, not only cannot constitute a reason to reject such a measure, but is in fact a factor to support that measure being preferred to the measure imposing an MPU.' ${ }^{27}$

This reasoning - that a choice to control retail pricing of alcohol through a minimum price in order to protect public health should be subject to strong scrutiny, because tobacco pricing case law indicates

20 Ibid, 46.

21 The case was first brought before the Outer House of the Court of Session in Scotland. It was then appealed to the Inner House of the Court of Session, which made the reference to the CJEU. The decision of the Inner House was then appealed to the UK Supreme Court.

22 Scotch Whisky (CSOH), n 1, 53.

23 Ibid, 54.

24 Ibid, 77.

25 Ibid, 79.

26 Case C-216/98 Commission v Greece EU:C:2000:571, and Case C-197/98 Commission v France EU:C:2010:111.

27 Scotch Whisky (CJEU), n 9, 48. Throughout the initial judgment the Outer House refers to Minimum Price per Unit (MPU), but in this paper we prefer the more common usage of MUP. 
that taxation could also protect public health - arguably contains two significant flaws. First, the CJEU should have distinguished between alcohol and tobacco consumption. ${ }^{28}$ Although both are harmful, the consumption of alcohol and tobacco are in no way directly comparable. All tobacco consumption is harmful, and essentially similar in nature. There is vastly more variation in the types of alcoholic beverages and their patterns and purposes consumption; therefore posing different risks of harm. ${ }^{29}$ Relying solely on increased taxation may have the effect of discouraging low-risk drinking while not sufficiently addressing harmful and hazardous drinking. This is because, in addition to potentially not increasing the price of the cheapest drinks sufficiently to discourage heavy and harmful drinking, for instance increasing the tax on specific categories of beverage such as wine, would have the effect of raising the price of all beverages consumed in any measure or location, which may encourage moderate drinkers to seek discounted stronger alcohol or move to multi-buy offers. ${ }^{30}$ Consequently, alcohol strategies should combine measures such as increased taxation and MUP, both of which have different and complementary objectives. ${ }^{31}$

Second, the CJEU should have distinguished the legal context in which its decisions on tobacco pricing were made. These decisions concerned the compatibility of national laws setting minimum prices for tobacco products with the provisions of the tobacco taxation directive. ${ }^{32}$ Pricing is one of the very few marketing tools available to tobacco producers that is not heavily restricted by EU law. The tobacco taxation directive ensures consistent treatment of tobacco products and fair competition with the objective of allowing price competition to drive the market. Any attempt to stifle price competition, for example through the imposition of minimum prices, is a challenge to the central tenet of the directive and will be subject to close scrutiny.

In contrast, price competition amongst retailers has not been protected as strongly under Article 34 TFEU since the ruling in Keck. For example, the judgments in LIBRO (concerning national legislation that prevented book retailers from selling German language books at prices below the prices set for them in legislation) and Colruyt (concerning a similar national prohibition on tobacco retailers selling cigarettes at prices lower than those indicated by the manufacturer or importer) reinforce the ruling in Keck that national rules regulating retail pricing practices constitute 'selling arrangements' that in principle fall outside the scope of Article 34 TFEU. ${ }^{33}$ Cases such as Belgapom (concerning a national prohibition on retailing goods at only a very low profit margin) indicate that singling out retailers for regulation will not necessarily trigger Article 34 . As the Advocate General explained, market conditions mean that domestic producers generally use the services of retailers to sell to consumers in their own Member State in the same way that foreign producers do; regulating retail pricing practices specifically

28 See the analysis below on the significance of this failure.

29 See for example: Peter Anderson, Lars Møller and Gauden Galea (eds), Alcohol in the European Union. Consumption, harm and policy approaches (WHO Europe 2012); J. Rehm and others, 'The Relation between Different Dimensions of Alcohol Consumption and Burden of Disease - An Overview' (2010) 105 Addiction 817; Laura Baglietto and others, 'Average Volume of Alcohol Consumed, Type of Beverage, Drinking Pattern and The Risk of Death From All Causes' (2006) 41 Alcohol and Alcoholism 664.

30 Luca Panzone, 'Alcohol tax, price-quality proxy and discounting: A reason why alcohol taxes may rebound' (2012) 63(3) Journal of Agricultural Economics 715.

31 'The diversity of alcohol-related problems and measures necessary to reduce alcohol-related harm points to the need for comprehensive action across numerous sectors': WHO, Global strategy to reduce harmful use of alcohol (WHO, 2010), 6.

32 Council Directive 2011/64 of 21 June 2011 on the structure and rates of excise duty applied to manufactured tobacco, OJ L 176/24, 5.7.2011.

33 Case C-531/07 Fachverband der Buch- und Medienwirtschaft $v$ LIBRO Handelsgesellschaft mbH EU:C:2009:276, 17-20; Case C-221/15 Etablissements Fr. Colruyt NV EU:C:2016:704, 32-41. The difference in outcomes between $L I B R O$ and Colruyt is attributable to the fact that the legislation in LIBRO discriminated against imports and the legislation in Colruyt did not. 
is not automatically liable to disproportionately impede the marketing of imported products. ${ }^{34}$ Consequently, applying the conclusions from case law that concerned manufacturer pricing of tobacco in the context of harmonising legislation to the retail pricing of alcohol in the context of Article 34 arguably ignores the legal context of the Scotch Whisky dispute and the Court's previous Article 34 case law.

Having said this, the Court may have made a deliberate effort in Scotch Whisky to develop stronger protection of retail price competition as a fundamental feature of the internal market. It has been argued elsewhere that the CJEU is, throughout this judgment, seeking to enhance the protected status of price competition. ${ }^{35}$ That is not to say that it must remain inviolate, but rather that any attempt to interfere with pricing is likely to be met with an enhanced level of EU law scrutiny.

With two conflicting views on the comparative effectiveness of MUP and taxation, Lord Carloway, the Lord President of the Inner House, ${ }^{36}$ applied the legal test set out by the CJEU, but preferred the factual findings of the Outer House. ${ }^{37}$ The Lord President spent considerable time in his judgment weighing the substantial body of evidence, including evidence made available after the CJEU ruling, concerning the effectiveness of MUP and other alcohol pricing interventions. ${ }^{38}$ After coming to the conclusion that a 'fundamental problem' of increased taxation is the absence of floor prices and the potential to offset in the pricing of other products, and that MUP unlike tax could be linked to alcoholic strength, ${ }^{39}$ the Lord President decided that:

'whatever arguments may be deployed against it, there is material ("evidence") which demonstrates that the alternative of increased tax, with or without a prohibition on below cost sales, is less effective than minimum pricing. ${ }^{40}$

The Inner House found that on the current evidence base MUP was the most effective policy to address the Scottish Government's primary objective of reducing harmful and hazardous alcohol consumption. The Scotch Whisky Association appealed this ruling to the UK Supreme Court, which handed down its judgment in November 2017, and we will consider that judgment later in this paper. ${ }^{41}$ However in the next section, we return to the CJEU's judgment, and assess its wider significance for the development of EU internal market law, and in particular for the role of evidence in proportionality analysis.

34 Case C-63/94 Belgapom v ITM and Vocarex EU:C:1995:270; Opinion of Advocate General Cosmas in Case C63/94 Belgapom v ITM and Vocarex EU:C:1995:81.

35 Angus MacCulloch, 'State Intervention in Pricing: An Intersection of EU Free Movement and Competition Law' (2017) 42 European Law Review 190.

36 In the Scottish court system the Court of Session is the highest civil court. It is comprised of the Outer House, which hears cases at first instance, and the Inner House, which hears appeals from the Outer House and the lower Sheriff Courts.

37 Scotch Whisky Association \& Others v Lord Advocate [2016] CSIH 77.

38 The evidence put forward by the Lord Advocate is considered at 125-143. The petitioner's response is at 149165.

39 Scotch Whisky (CSIH), n 37, 196 and 198.

$40 \mathrm{Ibid}, 200$. At 204 the Lord President also described certain benefits of MUP as being 'well documented'.

41 Scotch Whisky Association and others v The Lord Advocate and another [2017] UKSC 76. 


\section{Implications of the CJEU's Scotch Whisky Judgment for Future Internal Market Jurisprudence}

Scotch Whisky was decided at a point when the requirement to substantiate claims with some evidence was already established doctrine ${ }^{42}$ and when the CJEU had already started to qualify what 'evidence' means. In case law ranging from public health ${ }^{43}$ to road safety ${ }^{44}$ to health and safety, ${ }^{45}$ the CJEU has discussed the manner of evidence required to demonstrate the proportionality of measures, and has increasingly engaged with questions of evidence and proof over time. ${ }^{46}$ Against this background, we suggest that Scotch Whisky is unusual and important because it could provide a precedent from which the CJEU could extend its shift towards greater engagement with evidence into more highly sensitive policy fields.

Despite the CJEU's increasing engagement with evidence across most free movement case law, there are some fields in which the Court has declined to give detailed consideration to the manner in which Member States must substantiate the proportionality of their measures. Alcohol policy is one such field. In Aragonesa, the Court felt that it was 'sufficient to observe' ${ }^{47}$ that there was a link between alcohol advertising and consumption. In Franzen the Court observed that protection against alcohol related harm 'indisputably' 48 provided a ground for derogation from the free movement provisions without further consideration of the supporting evidence. In Rosengren the Court felt able to hold that 'it does not appear that there is, in all circumstances, an irreproachable level of effectiveness' ${ }^{49}$ of a measure without really discussing the public health evidence supporting such a conclusion in any detail.

Scotch Whisky is the first judgment on alcohol policy in which the CJEU discussed evidence within its proportionality assessment in significant detail. In addition to more general statements on how national courts should interpret evidence ${ }^{50}$ and the type of evidence they must consider, ${ }^{51}$ the CJEU drew specific inferences from the evidence presented to it on the comparative effectiveness of taxation and MUP as measures for reducing alcohol related harm.

This is unusual because alcohol policy is politically highly sensitive, and the Member States and the European Commission have insisted that it remain a national competence. ${ }^{52}$ The CJEU has historically been reluctant to disrupt this by dictating to Member States how they should justify national alcohol measures that conflict with the general free movement provisions. Scotch Whisky was the first alcohol control case in which it drew its own epidemiological conclusions from the evidence presented to it and then used these conclusions to form an opinion on the proportionality of a national alcohol

42 See for example Case C-333/08 Commission v France EU:C:2010:44, 97.

43 Case C-531/06 Commission v Italy EU:C:2009:315. See also: Case C-270/02 Commission v Italy EU:C:2004:78, 24; and, Case C-473/98 Toolex Alpha EU:C:2000:379, 45.

44 Case C-61/12 Commission v Lithuania EU:C:2014:17, 62 \& 67.

45 Case C-254/05 Commission v Belgium EU:C:2007:319, 36.

46 See for example Niamh Nic Shuibhne and Marsela Maci, 'Proving Public Interest: The Growing Impact of Evidence in Free Movement Case Law' (2013) 54(4) Common Market Law Review 965.

47 Case C-1/90 Aragonesa EU:C:1991:327, 15.

48 Case C-189/95 Franzen EU:C:1997:504, 76.

49 Case C-170/04 Rosengren EU:C:2007:313, 54.

50 Scotch Whisky (CJEU), n 9, 56.

51 Ibid, 64.

52 Notwithstanding the European Parliament and Council have both called for a renewed EU alcohol strategy: Motion for a Resolution on Alcohol Strategy (2015/2543(RSP)) B-0357/2015, 22.4.2015; Council Conclusions on an EU strategy on the reduction of alcohol related harm [2015] OJ C 418/6-8. 
control measure. This contrasts markedly with previous practice, in which the Court was content to leave the interpretation and application of the proportionality test entirely to the national court. ${ }^{53}$

A deliberately delicate approach to evidence has also been adopted by the CJEU in other politically sensitive policy fields, notably gambling policy. Prior to Scotch Whisky, the Court declared in Sto $\beta$ that governments must provide 'all the evidence of such a kind' to satisfy the Court on the issue of proportionality, ${ }^{54}$ but nevertheless insisted that a national gambling measure could not be disproportionate 'solely on the ground that that MS is not able to produce studies serving as the basis for the adoption of the legislation at issue'. ${ }^{55}$ This ruling was intended to clarify a statement in the Lindman case on the role of 'statistical or other evidence's6 in determining the risks connected to gambling and indicated that the CJEU was not willing to prescribe the type of evidence that must substantiate the proportionality of gambling measures. This stance was apparently reinforced in Pfleger, in which the Court held that 'a global assessment of the circumstances in which restrictive legislation ... was adopted and implemented ${ }^{57}$ was required, declining to comment on whether particular types of evidence should be adduced by national governments.

In politically less sensitive fields, characterised by increased levels of EU harmonisation, the CJEU by contrast has been far more willing to provide direct guidance on the type or quality of evidence required to demonstrate the proportionality of national measures, and has often drawn its own conclusions from that evidence. For example, in Greenham and Abel (concerning the marketing of foodstuffs) the Court held that bans on the marketing of foodstuffs 'can be adopted only if the alleged real risk for public health appears to be sufficiently established on the basis of the latest scientific data' $^{\prime 58}$ There are similar examples in case law ranging from food safety ${ }^{59}$ to urban waste water treatment ${ }^{60}$ to $\mathrm{GMO}$ animal feed. ${ }^{61}$

It would be possible for the CJEU to replicate the bold approach to evidence taken in Scotch Whisky in jurisprudence concerning other highly sensitive policy areas that are primarily the responsibility of Member States. The judgment has been relied upon by the Court or Advocate Generals a handful of times as authority for the proportionality test. ${ }^{62}$ Such a development should be treated carefully. The proportionality analysis in Scotch Whisky was based upon an adventurous judicial reading of the evidence base that was unprecedented in its policy context. One may question whether it is appropriate for this approach to proportionality to serve as the model for decisions in other areas of internal market jurisprudence, and particularly whether the CJEU should be as prescriptive regarding evidence in cases that deal with other politically sensitive policy areas. If governance of a complex issue lies mainly with the Member States, applying a heightened standard of evidence provision to

53 Case C-405/98 Gourmet International EU:C:2001:135, 33.

54 Case C-316/07 Stoß EU:C:2010:504, 71.

55 Ibid, 72. Emphasis added.

56 Case C-42/02 Lindman ECLI:EU:C:2003:613, 26.

57 Case C-390/12 Pfleger EU:C:2014:281, 52.

58 Case C-95/01 Greenham and Abel EU:C:2004:71, 42. Emphasis added.

59 Case C-382/10 Albrecht EU:C:2011:639, 27.

60 In Case C-390/07 Commission v UK, EU:C:2009:765, the entire case concerns the interpretation of evidence by the parties, on which the Court gives extensive direction.

61 Cases C-58/10 to C-68/10, Monsanto, EU:C:2011:553, 76.

62 See, Case C-591/17 Austria v Germany EU:C:2019:504; Case C- C-377/17 Commission v Germany EU:C:2019:562; Case C-151/17 Swedish Match EU:C:2018:938; Case C-329/16 Snitem EU:C:2017:947; Case C-52/16 SEGRO EU:C:2018:157; Case C-221/15 Colruyt EU:C:2016:704; Case C-148/15 Deutsche Parkinson Vereinigung EU:C:2016:776; Case C-114/15 Audace EU:C:2016:813; and, Case C-472/14 Canadian Oil Company EU:C:2016:171. 
national laws when they conflict with the general free movement provisions of the EU Treaties may result in gaps in governance emerging. When confronted with such a possibility, perhaps the CJEU and national courts might consider whether applying a rigorous evidential standard to national policies should be balanced against the disutility of Member States being prevented from pursuing particular policy objectives.

Despite these concerns the Scotch Whisky ruling has influenced heighted evidential standards in subsequent free movement case law. In Deutsche Parkinson Vereinigung, ${ }^{63}$ concerned the fixing of retail prices of medicinal products in pharmacies, the CJEU held that a state must produce 'specific evidence substantiating its arguments', ${ }^{64}$ and cannot rely on the 'yardstick of general conjecture, but on the basis of relevant scientific research' ${ }^{65}$ With reference to Scotch Whisky, it went on to hold that the national court 'must examine objectively, through statistical or ad hoc data, or by other means, whether it may reasonably be concluded from the evidence' ${ }^{66}$ that the measure was proportionate. This insistence on 'statistical or ad hoc data' is novel in the free movement case law and indicates the Court's willingness to endorse a heightened evidential standard. It is not clear whether this case is the beginning of a new trend, or an isolated example of Scotch Whisky's influence. No other cases that refer to Scotch Whisky have explicitly endorsed a heighted evidential standard. This does not mean, however, that such an endorsement will not take place on a broader scale.

It may be very suitable to hold Member States to a heightened standard of evidence provision in some fields of policy yet may not be suitable to do so in others. As we noted above, the Court did not appreciate the complexity of the alcohol control evidence base in relation to MUP. This is perhaps an inevitable and natural result when judges are not generally skilled technical or scientific experts. ${ }^{67}$ In fact, in many complex policy areas the nature and role of evidence is often not fully understood by scientists and policymakers themselves. ${ }^{68}$ However, this should not automatically imply that courts should defer entirely to governments when legal questions turn on the interpretation of complex evidence, as evidence is only one element to be factored into decisions. ${ }^{69}$

Aside from the approach to evidence, other aspects of the Scotch Whisky approach to proportionality - specifically the way in which legitimate objectives are identified - could also be influencing free movement jurisprudence. The Lietuvos Respublikos Seimo nariu grupe $\dot{e}^{70}$ case concerns the issue of whether the milk sector is exhaustively harmonised by Regulation 1308/2013 establishing a common organisation of the markets in agricultural products. The Advocate General carefully considered the scenario in Scotch Whisky in his Opinion:

63 Deutsche Parkinson Vereinigung, ibid.

64 Ibid, 35.

65 Ibid, 42.

66 Ibid, 36.

67 This limitation of judges has been known for many years: J Wesley, 'Scientific evidence and the question of judicial capacity' (1983) 25 William and Mary Law Review 675; and, S Jasanoff and D Nelkin, 'Science, technology, and the limits of judicial competence' (1981) 22 Jurimetrics Journal 266.

68 M Juntti et al, 'Evidence, politics and power in public policy for the environment' (2009) 12(3) Environmental Science and Policy 207; and, R Brownson et al, 'Evidence-based public health: A fundamental concept for public health practice' (2009) 30 Annual Review of Public Health 175.

69 See L Morales, 'Taking facts seriously: Judicial intervention in public health controversies' (2015) 8(2) Public Health Ethics 185; and, E Hammond Meazell, 'Super deference, the science obsession, and judicial review as translation of agency science' (2010) 109 Michigan Law Review 733.

70 Opinion of AG Bobek in Case C-2/18 Lietuvos Respublikos Seimo nariy grupe EU:C:2019:180. 
'the objective of the protection of public health was not specifically part of the equation in the balance struck by the EU legislature at EU level ... That objective was part of a different national regulatory regime, guided by different considerations, which only incidentally overlapped with the EU one. The national rule at stake was a measure applicable only at the retail stage. Thus, although retail is naturally also a stage (the last stage) of the marketing chain, the overlap and thus ensuing conflict between EU rules and the national rules was indeed marginal'. ${ }^{71}$

Thus, if the question of pre-emption is to depend on identifying the stated objectives of national governments in pursuing national policy measures, one might also question whether Scotch Whisky should become the model for analysis, given the unusual way in which the CJEU characterised the objectives of MUP during its application of the comparative effectiveness test.

\section{Domestic Courts' Application of the CJEU's Approach to Evidence in Scotch Whisky}

There have been several significant judgments handed down in the UK after the CJEU preliminary reference in Scotch Whisky. The judgments highlight problems that will face any EU domestic court that must implement the CJEU's approach to real world interventions.

The first examples come from the complex judicial review proceedings in BAT $v$ SoS for Health ${ }^{72}$ This application for judicial review by tobacco companies challenged the UK's introduction of plain tobacco packaging. One of the key arguments was the proportionality of the measure.

The High Court judgment runs to around 1,000 paragraphs across 386 pages, ${ }^{73}$ reflecting the complexity of the arguments submitted by the applicants. We can, however, identify two general themes in relation to the assessment of proportionality. First, the respective roles of the court and legislature, and second, the difficulty of dealing with complex evidence.

Mr Justice Green split his proportionality analysis into three main parts, stating that the court must consider:

(i) the aims of the measure and its legitimacy; (ii) whether the measure in question is suitable or appropriate to achieve the (legitimate) aims pursued; and (iii) whether the measure is necessary to achieve that objective' ${ }^{74}$

To that he added a more contentious fourth element, 'proportionality strictu sensu', a consideration 'whether the burden imposed by the measure is disproportionate to the benefits secured'. ${ }^{75} \mathrm{Mr}$ Justice Green noted that this element was not consistently applied, and for reasons that will be discussed later, it is now clear that its consideration was not required. In each of those limbs he found that on the evidence before him the measures adopted were proportionate. It must be noted that the

71 Para 42

72 BAT v SoS for Health [2016] EWHC 1169 (Admin). The Article 34 TFEU argument was not pursued on appeal, but proportionality more generally was still an issue: $R$ (on the application of British American Tobacco UK Ltd) v Secretary of State for Health [2016] EWCA Civ 1182; [2017] 3 WLR 225; [2017] 2 All ER 691.

73 On the length of the EWHC judgment see the view of the EWCA, BAT (EWCA), ibid, 2. The EWHC judgment does have a very helpful contents index to aid navigation.

74 BAT (EWHC), n 72, 428.

75 Ibid, 429. The contested fourth limb has a long history; see, for example, Takis Tridimas, 'Proportionality in Community Law: Searching for the Approriate Standard of Scrutiny' in Evelyn Ellis (ed), The Principle of Proportionality in the Laws of Europe (Hart Publishing 1999). 
context of proportionality assessment in judicial review and free movement cases will differ to some extent, ${ }^{76}$ but the issues the High Court faced in applying the test were essentially similar.

Mr Justice Green also gave his perspective on the difficulties in dealing with such disputes. In relation to the proper role of the courts he recognised that when courts face proportionality review they must:

'reconcile the need to review [the] new evidence and form [their] own judgment with the need to pay proper respect to the fact that [they are] assessing, in a judicial review, the legality of legislation promulgated by a democratically elected Parliament' ${ }^{\prime}{ }^{77}$

This problem is compounded when the court 'adopts the mantle and garb of the decision maker and then, within the confines of the appropriate margin of appreciation, applies up to date evidence', ${ }^{78}$ which could not have been addressed by the legislature. The adoption of the term 'margin of appreciation' in this passage was, as we shall see later, unhelpful. Courts must move beyond a simple review of the legislature's judgement when new evidence becomes relevant and must take their own view of whether a measure is appropriate or necessary in such circumstances.

In relation to the complexity of evidence, Mr Justice Green noted that much of the evidence presented 'is not the sort that would be easily digestible and readily understood by a Court', ${ }^{79}$ and that:

'under the instruction now given to Courts hearing proportionality challenges to arrive at their own conclusions upon the basis of up to date evidence, there is a real risk that Courts will find themselves overwhelmed by highly technical and complex evidential disputes which they may not be capable of resolving' ${ }^{80}$

His conclusion was that:

'if this is so then there is a consequential risk that perfectly sound applications for judicial review on proportionality grounds will fail, where otherwise they should have succeeded, simply because the judicial process is not well suited to untangling the complexities involved' ${ }^{81}$

Given the extent and nature of the evidence considered in this case it is no wonder that he was concerned that the courtroom is not the right place to resolve scientific disputes about methodology or the robustness of findings. ${ }^{82}$ The scientific question of whether price interventions work to reduce alcohol related harm, for instance, has alone generated a vast web of evidence. ${ }^{83} \mathrm{In}$ fact, there is so much evidence on the effectiveness of alcohol policy generally that scientists are now producing

76 See, for instance, the discussion of $R$ (on the application of Lumsdon and others) $v$ Legal Services Board [2015] UKSC 41, 433.

$77 B A T$ (EWHC), $\mathrm{n} 72,632$. In this case the legislation was The Standardised Packaging of Tobacco Products Regulations 2015, SI 2015/829.

78 Ibid.

79 Ibid, 633.

$80 \mathrm{Ibid}, 37$.

81 lbid.

82 See, for instance, his comments, ibid, at 411.

83 Elder et al examined seventy two relevant studies in Elder et al, 'The effectiveness of tax policy interventions for reducing excessive alcohol consumption and related harms' (2010) 38(2) American Journal of Preventive Medicine 217, and Wagenaar et al examined fifty articles in Wagenaar et al, 'Effects of alcohol tax and price policies on morbidity and mortality: A systematic review' (2010) 100(11) American Journal of Public Health 2270. 
systematic reviews of systematic reviews. ${ }^{84}$ Given the CJEU's push towards the importance of evidence in proportionality cases it is inevitable that courts will be drawn into these matters. ${ }^{85}$

When BAT came before the Court of Appeal, notwithstanding the detailed consideration displayed in the lengthy High Court judgment, one of the challenges to the findings on proportionality was that the judge had not properly considered all the evidence presented, as it was not specifically referred to in the judgment. Lord Justice Lewison dismissed this argument making it clear that the fact that a specific element of evidence is not referred to cannot be inferred to mean that it has not been taken into account. ${ }^{86}$ The Court of Appeal did however criticise the High Court's reference to a 'margin of appreciation' when considering legislative measures. That term has a lengthy history, particularly in ECHR jurisprudence, and is best avoided where its particular meaning is not specifically being imported. ${ }^{87}$ Relying on the Supreme Court's approach in In re Medical Costs for Asbestos Diseases (Wales) Bill ${ }^{88}$ and Mathieson $v$ Secretary of State for Work and Pensions ${ }^{89}$ it referred instead to a measure of 'respect' which should be accorded to the legislature. ${ }^{90}$

The Court of Appeal turned to the necessity of the measure using a test of 'objective reasonableness' 91 based on Scotch Whisky, and addressed the complexity of the evidence. The judgment stressed that it was the role of the court to undertake an 'assessment of the evidence adduced by the member state' ${ }^{92}$ That assessment will include any evidence that opposes the measure; however, the court is not expected to resolve disputes between 'technical experts', simply to use that evidence to test the evidence upon which the Member State relies. The Court of Appeal found that the trial judge was:

'entitled to accept the Secretary of State's evidence that none of the claimed alternatives, including increased taxation, would achieve all of the objectives pursued by the Regulations and that they should be regarded instead as complementary measures forming part of a comprehensive tobacco control strategy'. ${ }^{93}$

The Court of Appeal did not accept Mr Justice Green's technical recommendations as to how complex evidential matters should be handled, rather stressing that each court seized of a dispute should take its own decision as to the most appropriate approach to take within the Scotch Whisky test. ${ }^{94}$

These judgments highlight the nuanced and difficult role that a court must face. They must balance appropriate 'respect' for legislative policy choices alongside a robust examination of both policy choices and the evidence that the legislature relied upon, and any subsequent developments in that evidence base. Courts are clearly capable of undertaking such a task, but it is also clear that they have

84 See for example: Martineau et al, 'Population-level interventions to reduce alcohol-related harm: An overview of systematic reviews' (2013) 57(4) Preventive Medicine 278.

85 As we shall see below Mr Justice Green was himself forced to return to this issue in a subsequent case.

86 BAT (EWCA), n 72, 210.

87 The term has a lengthy history in both human rights jurisprudence and EU law. For discussion of its history see, for instance, JA Sweeney, 'A 'margin of appreciation' in the internal market : lessons from the European Court of Human Rights' (2007) 34 Legal Issues of Economic Integration 27.

88 [2015] UKSC 3, [2015] AC 1016.

89 [2015] UKSC 47.

$90 B A T$ (EWCA), n 72, 226-227. In Mathieson, ibid, 25, it was explained that the extent of the 'respect' could be 'albeit of differing width'.

91 BAT (EWCA), n 72, 246.

92 Ibid. Emphasis in original.

93 Ibid, 243.

94 Ibid, 253. 
to be very careful not to go beyond the limits of their role in seeking to substitute their policy decision for that of the legislature.

This role was explored by the UK Supreme Court in the Scotch Whisky appeal itself. ${ }^{95}$ Lord Mance's rhetorical question of whether 'it is irrelevant how much damage results to the ordinary operation of the EU market' if there is only one way of achieving a reasonable objective is revealing. ${ }^{96}$ How exactly does one balance a health benefit against a restriction on trade or competition? As Lord Mance made clear, these are 'two essentially incomparable values', and that 'it is not for any court to second-guess the value which a domestic legislator may decide to put on health' ${ }^{97}$ The judgment provided a stark illustration of the impossibility of balancing these competing interests:

'Would or should a court intervene because it formed the view that the number of deaths or hospitalisations which the member state sought to avoid did not "merit" or was not "proportionate to" the degree of EU market interference which would be involved? I very much doubt it'. ${ }^{98}$

The Supreme Court recognised that there was a sizeable penumbra of uncertainty as to how consumers or industry would respond to the introduction of MUP. The question for the Court was whether the Member State had properly considered the evidence that was available, however uncertain, and whether they had acted proportionately in response to it. By rejecting the proportionality 'strictu sensu' approach, as discussed in $B A T$, ${ }^{99}$ the Court reduced the need to 'set off' or 'balance' the benefit of the measure on one hand with the restriction on trade or competition on the other. The focus should rightly be on the achievement of the beneficial aim of the measure; if it can only be achieved through the means identified it must then be proportionate, as long as the evidence, given the current state of knowledge, shows that the measure should achieve that aim. Proportionality, in the sense of comparing one measure with another, will only be a live issue if it is contended that another measure might be able to achieve that same aim while having a lesser impact on trade or competition.

In the case of MUP the Supreme Court was satisfied that higher taxation would simply not achieve the same targeted impact as MUP, and was therefore not a viable alternative for the purpose of the necessity test - 'minimum alcohol pricing will much better target the really problematic drinking to which the Government's objectives were always directed'. ${ }^{100}$ It was also clear that the policy choices of the democratically accountable legislature were to be given respect:

'the Scottish Parliament and Government have as a matter of general policy decided to put very great weight on combatting alcohol-related mortality and hospitalisation and other forms of alcohol-related harm. That was a judgment which it was for them to make, and their right to make it militates strongly against intrusive review by a domestic court'. ${ }^{101}$

This is a robust response to how the CJEU conceptualised a national court's obligations with respect to proportionality and evidence. It refocuses the role of the Court on testing the evidence put forward to justify a measure and testing any alternative suggested. In this process, it is inevitable that a court should draw some inferences from the evidence base. This must be done to some extent - in order to determine whether a government was entitled under the law to reach particular conclusions based on the evidence available, a court would have to work through the same process and scrutinise the

95 Scotch Whisky (UKSC), n 41.

96 Ibid, 47.

97 Ibid, 48.

98 Ibid, 49.

$99 B A T(\mathrm{EWHC}), \mathrm{n} 72$.

100 Scotch Whisky (UKSC), n 41, 63.

101 Ibid. 
inferences that a government made and the conclusions that it drew, as well as the inferences and conclusions that were not made or drawn but were reasonable based on the available evidence. In this way, a court will hold a government to account with regard to the way in which it uses evidence to justify policy. However, Member States must be given scope to choose the best means they have available to achieve legitimate policy goals. This means that a court's engagement with evidence should be restricted to testing the reasoning of a government with respect to that evidence. The point at which a court's activities cross from warranted testing of a government's reasoning to unwarranted imposition of their own assessment of the evidence base is obviously blurred, which is why the task of the Supreme Court following the judgment of the CJEU was so difficult.

The Supreme Court's formulation of national courts' obligations therefore had to delicately reflect the different roles that the legislature and the courts have in relation to policy measures. While it is court's role to determine whether the aims pursued by a government could be supported as a matter of law by the evidence available, it should not be a court's role to say that the legislature has chosen the wrong aim for the measure or has adopted too high a level of protection. While it is a court's role to determine whether a government can restrict certain public interests as a matter of law in order to promote others, it should not be a court's role to 'balance' two 'incomparable values' like health and trade in such a way that the court, rather than the legislature, ends up choosing which value should receive greater protection.

After the guidance provided by the UK Court of Appeal and Supreme Court, it is disappointing that the High Court took a step backward in EU Lotto. ${ }^{102}$ Mr Justice Green was again called to rule on a challenge to the prohibition on parasitic gambling on the non-UK EuroMillions lottery draws offered into the UK by online gambling providers. Regulations were introduced ${ }^{103}$ that were designed to close a loophole whereby UK gambling providers were prohibited from offering parasitic gambling products on UK lottery draws, but EU providers could offer such products based on the analogous non-UK lottery draws to UK gamblers. ${ }^{104}$ The extension of the parasitic gambling prohibition was challenged as a breach of Article 56 TFEU on the freedom to provide services, which was not justified as a proportionate restriction on the basis of public policy. Rather than rely directly on Scotch Whisky, the parties arguments had focused on the slightly earlier UKSC judgment in $R$ (Lumsdon) $v$ Legal Services Board. ${ }^{105}$ The adoption of the approach in Lumsdon makes direct comparison on the judgments more complex but the High Court did adopt the classic 'appropriate and necessary' proportionality test, with the addition of a pre-cursor that court must consider, 'the aims of the measure and its legitimacy'. ${ }^{106}$

Although it is not explicitly referenced we suggest that the need to identify the proper aim of measure stems from Scotch Whisky. The High Court also took on many of the lessons with regard to the importance of evidence. In paragraph 58, Mr Justice Green lays down a number of evidence related points that the courts should focus on, including: the need to use the most up to date evidence, the need to adduce new evidence, the types of evidence required, and the different level of scrutiny required for post-facto evidence. The High Court was willing to address the evidence presented in real detail but was nevertheless wary of extending their analysis too far, stating that the proportionality

\footnotetext{
102 EU Lotto Ltd \& Ors v Secretary of State for Digital, Culture, Media and Sport [2018] EWHC 3111 (Admin).

103 The Gambling Act 2005 (Operating Licence Conditions) (Amendment) Regulations 2018, SI 2018/453.

${ }^{104} \mathrm{~A}$ unique feature of the EuroMillions lottery is that it is a multistate lottery where a single draw in Paris is the basis for a lottery across several EU Member States. While one can technically be betting on the German EuroMillions draw, the numbers drawn will, of course, be the same as the numbers in the UK draw.

${ }^{105}$ R (Lumsdon) v Legal Services Board [2015] UKSC 41.

${ }^{106}$ EU Lotto, n 102, 57.
} 
test 'can be applied with considerable flexibility and for this reason it does not involve the court usurping the legitimate function of the decision maker or legislature' ${ }^{107}$

The High Court did however spend considerable time discussing the legislature's 'margin of appreciation', ${ }^{108}$ a contested concept which was explicitly rejected by the Court of Appeal, therefore noticeably departing from the model of analysis in Scotch Whisky and BAT. Given the Court of Appeal's rejection of the 'margin' in $B A T,{ }^{109}$ it is worrying that the High Court, while drawing explicitly on $B A T$, consistently refers to it. The High Court's failure to draw any clarity from its analysis based on the 'margin' demonstrates its problematic nature, and it is clear from the judgment that the parties' arguments were presented on this basis. Nevertheless, in some parts of its judgment the High Court did show an ability to comfortably negotiate complex policy choices made by the legislature without having to frame the question in relation to any 'margin'. ${ }^{110}$

\section{The Importance of Policy Framing by National Governments after the Scotch Whisky Litigation}

Although courts have a difficult responsibility in determining whether Member States have produced enough evidence of sufficient quality to support the proportionality of their measures, the outcome of any proportionality review depends on more than just the court respecting the boundaries of its role. It also depends upon a Member State presenting its measure, and the evidence supporting it, in a manner that makes the proportional nature of the intervention as clear to the court as possible. It is true that courts may factor over-simplifications of the evidence base into their judgment - the CJEU's assumption, in Scotch Whisky, that conclusions on the role of taxation in tobacco policy are transferrable to alcohol policy (and the resulting erroneous decision that taxation could be an alternative measure to MUP) is a prime example. However, the CJEU was led to this assumption largely as a result of the Scottish Government's portrayal of MUP as a measure fulfilling a genuinely twofold purpose. But for this framing of the policy the CJEU may not have had cause to consider taxation as a viable alternative policy.

The CJEU's extensive comments on assessing evidence provided an opportunity for the Scottish Government to re-frame the evidence base and the objectives of the legislation before the Inner House and UKSC. This allowed the Scottish Government to introduce new evidence in the latter hearings which clarified and highlighted that the priority of a minimum price was to target hazardous and harmful drinkers, with any general population health benefits being of secondary concern. The Supreme Court emphasised this reframing as part of their conclusion that MUP was proportionate:

'it was never, and is not now, the aim or target of the Scottish Parliament and Ministers to reduce consumption, even by hazardous and harmful drinkers, and still less by moderate drinkers, to the maximum extent possible regardless of possible economic or social consequences ... The more recently available information from the University of Sheffield study of April 2016 merely underlines the appropriateness of a more targeted approach in this connection'. ${ }^{111}$

The CJEU ruling did not have the effect, as many media commentators claimed at the time, of declaring the Scottish MUP measure to be disproportionate ${ }^{112}$ - the effect it had was to put Member States on

\footnotetext{
107 Ibid, 58.

108 See, for example, ibid, 58, 76, and 96.

109 BAT (EWCA), n 72, 226-227.

${ }^{110}$ EU Lotto, n 102, 77.

111 Scotch Whisky (UKSC), n 41, 37.

112 See, for example, BBC News, 'Minimum alcohol pricing plan "may breach EU law"', <http://www.bbc.co.uk/news/uk-scotland-35160396> (last accessed 13 August 2019)
} 
notice that if measures are not presented precisely, in terms of their objectives and the relative suitability of genuine alternatives, they risk being interpreted as disproportionate. Therefore, Member States must pay attention to the framing of novel trade-restrictive public policies, for which the available evidence is less robust or more marginal.

Framing can be understood as the process of 'highlighting how issues can be conceptualized and represented in different ways by political actors in a strategic attempt to further their interest', and is 'an issue of great importance in policy debates as it opens up certain policy responses whilst precluding others' ${ }^{113}$ Specifically in relation to the defence of legislation in litigation, framing refers to the manner in which the relationship between the objectives of the legislation, its target population and the evidence base is presented. The ability of the Scottish Government to re-frame their MUP measure to reemphasise the priority given to the targeted aspects of the policy was important to the eventual outcome of the Scotch Whisky litigation. ${ }^{114}$

It is also clear that the framing of measures must refer to socio-economic context. There is no onesize-fits-all rationale for measures in fields such as public health, which could be adopted in different forms, and which could be utilised to address different public health problems in different countries. The CJEU emphasised that when assessing the proportionality of measures national courts must 'determine the relevance of the evidence adduced by the competent national authorities' ${ }^{\prime 15}$ - in other words, not all evidentiary contexts are the same, and governments must satisfy courts that a measure is appropriate and necessary in its particular national context. The High Court in EU Lotto also stressed that there was, 'a correlation between the remoteness of the risk being protected against and the cogency of the evidence required to justify intervention' ${ }^{116}$

The issue of framing to reflect the particular national context is especially important now that it is clear that the Scotch Whisky litigation has not deterred objections to subsequent and very similar MUP regimes - the delay to the Welsh scheme is likely only the first example. In light of this we suggest two practical considerations for governments and legislatures when framing measures. First, the objectives of a policy must be linked to the particular situation that prevails in the country in which it is adopted, and the evidence that the policy will work in that context. The BRIA produced for Scotland's MUP legislation noted that alcohol consumption in Scotland has risen by $11 \%$ in the last two decades, and that Scotland has one of the fastest growing rates of chronic liver disease, both in the context of falling consumption rates in most Western countries. A convincing case could therefore be made on the appropriateness and necessity of MUP in these circumstances. Not all countries experience alcohol related harm in the same way; meaning that the particular application of the policy must be explained in specific rather than general terms. The fact that a drop in alcohol consumption was observed one year after the introduction of MUP in Scotland ${ }^{117}$ does not suggest that the same results will inevitably be seen in Wales, for example. Furthermore, some forms of evidence such as modelling (relied on heavily to defend the Scottish MUP legislation) must be carefully adapted to different country contexts. This is because the parameters necessary for the construction of an accurate model,

\footnotetext{
113 Hawkins and Holden, 'Framing the alcohol policy debate: industry actors and the regulation of the UK beverage alcohol market' (2013) 7(1) Critical Policy Studies 53, 54.

114 The ability to re-frame policy also allowed the Secretary of State to rely on new evidence of a 'lead-in' risk in EU Lotto.

115 Scotch Whisky (CJEU), n 9, 56.

${ }^{116}$ EU Lotto, n 102, 91.

117 See Monitoring and Evaluating Scotland's Alcohol Strategy (MESAS): Monitoring Report 2019, available online at http://www.healthscotland.scot/media/2587/mesas-monitoring-report-2019.pdf (last accessed 13 August 2019).
} 
such as consumer elasticities on price, can vary significantly between countries. ${ }^{118}$ This is why the Sheffield Alcohol Policy Model, one of the key elements of the evidence base in the Scotch Whisky litigation, required adaptation for Scotland, Wales, Canada, Northern Ireland and the Republic of Ireland. ${ }^{119}$ Governments must be thorough and specific in identifying the harm that a policy targets, and the evidence that demonstrates that the policy will be effective.

Second, governments have to emphasise the particular role that a policy plays within their wider regulatory strategy. Part of the unusual nature of the CJEU's Scotch Whisky judgment was the detailed acknowledgement of the strategic context within which MUP was being adopted. This, if anything, led the UKSC to conclude that MUP was an appropriate measure in the Scottish context. The presentation of a measure as playing a role within a wider strategy in order to pass the appropriateness review lays crucial groundwork for the necessity review - this is because it is essential that a package of measures is seen as complimentary, operating in tandem to achieve broader goals, rather than as potential alternatives. This was an essential point of departure between the CJEU and the UKSC, as the UKSC viewed tax as constituting no real alternative to MUP, but rather as serving different and complimentary purposes. The importance of the appropriate framing of a targeted and innovative policy during policy debates cannot therefore be understated. ${ }^{120}$ Policies that may be seen as competing for regulatory attention much be positioned as being effective only when implemented together, so that a court is clear on the relationship between individual interventions and wider strategy when it comes to assess the necessity of those individual interventions.

A good test for the importance of rigorous framing of public health measures might be provided by legislative measures on alcohol that have recently been adopted in Ireland. The Public Health (Alcohol) Act 2018 was passed after over two years of political debate, and contains five main policy initiatives - a minimum unit price combined with labelling regulations, advertising restrictions, retail space regulations, and restrictions on sale and supply. ${ }^{121}$ The objectives of the legislation are stated in the accompanying Regulatory Impact Assessment to be 'ensur[ing] that the supply and price of alcohol is regulated and controlled in order to minimise the possibility and incidence of alcohol related harm; and to delay the initiation [and] use of alcohol by children and young people'. ${ }^{122}$

If the compatibility of this legislation with EU law were to be challenged, aligning it with the protection of young people's health may prove to be an important framing device. In Philip Morris Brands, the CJEU was receptive to arguments that the extensive set of measures adopted in the Tobacco Products Directive should be considered necessary and appropriate because they aim in particular to protect

${ }^{118}$ Chalmers et al, 'Real or perceived impediments to minimum pricing of alcohol in Australia: Public opinion, the industry and the law' (2013) 24 International Journal of Drug Policy 517, 518.

119 See https://www.sheffield.ac.uk/scharr/sections/ph/research/alpol/sapm (last accessed 13 August 2019).

120 On the importance of framing interventions within policy debates to ensure that the nature and target of the intervention is perceived as legitimate see, for example: Hilton et al, 'Implications for alcohol minimum unit pricing advocacy: What can we learn for public health from UK newsprint coverage of key claimmakers in the policy debate?' (2014) 102 Social Science and Medicine 157; and, Katikireddi et al, 'Changing Policy Framing as a Deliberate Strategy for Public Health Advocacy: A Qualitative Policy Case Study of Minimum Unit Pricing of Alcohol' (2014) 92(2) Millbank Quarterly 250.

${ }^{121}$ For further information on the Bill, see the references in O Bartlett, 'The compatibility of Ireland's Public Health (Alcohol) Bill with EU law' (EULawAnalysis, 13 October 2018), http://eulawanalysis.blogspot.com/2018/10/the-compatibility-of-irelands-public.html (last accessed 13 August 2019).

122 Regulatory Impact Analysis, Public Health Alcohol Bill, available online at https://health.gov.ie/wpcontent/uploads/2016/05/Regulatory-Impact-Analysis-Public-Health-Alcohol-Bill.pdf (last accessed 13 August 2019), 3. 
the health of young people from the risks of tobacco smoking. ${ }^{123}$ The protection of children has proved to be an effective frame in several other cases that dealt with both EU and Member State health and consumer protection related measures. ${ }^{124}$ However, such framing does come with certain risks. Arguments can be made that a suite of strong measures that apply to the population generally are not necessary if a specific objective of such measures is to protect children in particular. However, the CJEU clarified in Solgar Vitamin's France that:

'the taking into account of the varying degrees of sensitivity of different consumer groups allows a Member State to apply [certain measures] for a specific group of consumers, such as children, to the whole population only if that measure is limited to what is necessary to protect the health of the persons belonging to that group, and only if that measure is proportionate to the objective it pursues, and that objective cannot be attained by measures which are less restrictive to trade within the European Union'. ${ }^{125}$

Consequently, measures such as the Irish Public Health (Alcohol) Act 2018 might take advantage of the children's health protection frame as a way to steer the analysis of proportionality, so long as they are careful to demonstrate exactly how each of the measures are needed to ensure that children are protected from the harmful effects of alcohol.

Scotch Whisky does not have to increase uncertainty in policymaking - in fact it should be seen as increasing certainty for governments. Courts are directed to find experimental and innovative policies proportionate if such a conclusion may reasonably be reached upon an objective review of the evidence. If a piece of legislation is sufficiently well framed, the risk of an innovative, or experimental, policy that is evidentially effective being found disproportionate will be significantly decreased.

\section{Conclusions}

There are challenges for policymaking that stem from enhanced proportionality scrutiny by the courts; particularly in areas like public health where innovative policies may be subject to review. Courts are ill-equipped to evaluate and interpret complex public health evidence. The use of evidence in policymaking should be the preserve of the legislature charged with making complex policy decisions. Policymakers should, we argue, not be fearful of proportionality analysis, but the shift in emphasis that comes from the Scotch Whisky ruling does have greater implication for the domestic courts. Those courts will now be required to engage with innovative policymaking more frequently and will have a vital role to play in assessing the robustness of the evidence adduced by Member States to support those policies. That will take many courts into new territory, but there are real grounds for optimism. The early examples we have from the UK is that the courts can effectively rise to this challenge and discharge that role effectively. The High Court in $B A T^{126}$ arguably went too far in its analysis, and provided a chastening example of the nature of the problems that domestic courts can face, but other cases, such as EU Lotto, show the courts have been able to assess situations without apparent difficulty. ${ }^{127}$ There is no reason to assume that the courts in any other Member States are any less well equipped.

The main lesson from the Scotch Whisky litigation for policymakers and legislatures is the importance of the correct framing of their policy interventions to withstand proportionality analysis. It is vital that

\footnotetext{
${ }^{123}$ Case C-547/14 Philip Morris Brands EU:C:2016:325, 170-177.

124 See for example: Case C-220/17 Planta Tabak EU:C:2019:76; Case C-151/17 Swedish Match EU:C:2018:938; Case C-244/06 Dynamic Medien EU:C:2008:85; and, Case C-434/04 Ahokainen EU:C:2006:609.

125 Case C-446/08 Solgar Vitamin's France EU:C:2010:233, 61.

126 BAT (EWHC), $\mathrm{n} 72$.

127 See, also, Rostron v Guilford BC, n 4, and Transport for London v Uber London Limited and others [2018] EWCA Civ 1213.
} 
policymakers present their policy thoroughly, setting out the relationship between the policy objective of the measure, the relevant target population, and the evidence base for the effectiveness of that policy. That is not to say that all policies will have the same level of evidential backing. Innovative policies will, necessarily, have a more limited evidence base; either because the intervention is novel, or because the policy is to operate in a new context. In situations such as these, policymakers must take care to ensure that the frame in which they present the policy clearly ties the available evidence with their policy goal and policy context. If policymakers overstate the evidence base or present the aims of the intervention in an overly broad way there are real risks that this will make the defence of that policy before the courts much more difficult. Statements that make political sense when 'pitching' an intervention during the cut and thrust of policy debate do not always stand up well during forensic proportionality analysis. If a policy is demonstrably targeted at a real policy problem and there is good evidence of its potential effectiveness the courts have shown that they will accord the legislature's role in making complex policy decisions an appropriate level of respect. If the policymakers leave ambiguity in their framing and/or fail to show how an intervention is connected with wider policy in the field, they increase the risk of potential challenges being successful. 